\title{
PARTICIPATION OF THE ONLINE MEDIA AUDIENCE IN WINNING THE COMPETITION OF THE MASS MEDIA INDUSTRY IN INDONESIA (CASE STUDY : LIPUTAN 6.COM)
}

\author{
Bayquni BAYQUNI \\ Prof.Dr.Moestopo (Beragama) University, Indonesia \\ bayqunibayu15@gmail.com
}

\begin{abstract}
The background of this research is New Media or also called Online Media, now it has become an important and important need by the community, considering that today's life cannot be separated from Internet activities. This is the problem formulation of this research, the researcher wants to analyze how Liputan6.com can carry out media convergence according to market needs, so that liputan6.com can win the competition in the New Media or New Media industry. By looking at the formulation of the problem, it will be seen how the convergence in online media is carried out. This study uses a constructivist paradigm, a qualitative approach with data collection techniques, namely interviews and documentation data. Another theory used in this research is the Media Convergence Theory which was introduced by Henry Jenkins to take a technological approach, which states that online media must contain media convergence criteria, it is stated that online media can become economic convergence if it meets criteria containing elements of convergence, whether economic convergence or convergence, technology, social convergence, cultural convergence and global convergence which contains reducing the boundaries of space and time. The results of research on Liputan6.com stated that. In carrying out the Convergence of Coverage 6.com converges on the economy, on social and on culture, which is more directed at reporting to young people. In addition, Liputan 6.com also carries out cultural participation by creating affiliate program packages, expressions, collaboration of problem solving and connection. By engaging the audience with a term called citizen journalism, so that the audience will believe that what is conveyed contains elements of truth, and the last Commodification is Cybernatics where the limitations of space and time disappear when directed and packaged according to the purpose of Liputan6.com in informing the news. The results of the research on Liputan6.com can be concluded that Liputan6.com has fulfilled the elements in carrying out cultural participation in order to capture the competition in the New Media industry.
\end{abstract}

Keywords: Convergence, Cultural Participation, Online Media, New Media Coverage 6.com, Audience

\section{BACKGROUND}

Online media, along with the development and progress of the times, have a strong role in shaping people's thoughts about a reality. Using the paradigm of Peter D. Moss (1999) as expressed by Dedy Nur Hidayat in the introduction to the book Framing Analysis, mass media discourse, including newspaper news, uses cultural constructs produced by ideology because as mass media products, newspaper news uses a certain framework to understand reality. social. Through their narratives, newspapers offer certain definitions of human life: who is the hero and who is the villain; what reasons are reasonable and not; and what solutions should be taken and left behind (Eriyanto 2009, p. 10 )

Now, since human daily activities are increasingly crowded, the use of online media in terms of accessing news has also increased. Every print media then flocked to create an online version to take part in market competition. The existence of online media has now become an inseparable part of people's lives, because online media has a role to convey information about events or events that have occurred both at home and abroad more quickly and easily accessible.

The hallmark of the mass media is its ability to cause simultaneous (simultaneous) on the part of the audience in receiving the messages that are spread. Messages conveyed by the mass media through magazines, newspapers, tabloids, books, television, radio, internet, and films are received simultaneously by a wide audience of thousands or even tens of millions. A good mass media should carry out the same function as mass communication as stated by Harold Laswell, including to inform (to inform), to educate (to educate), and to entertain (to entertain). According to Law No. 40 of 1999 concerning the Press, that the function of the press is to inform, educate, entertain, and carry out social control (social control) both on public behavior and on the authorities. (Law No. 40 of 1999 on the press)

In the last ten years or so, the mass media has grown very rapidly. In the past, the types of mass media consumed by the public were only print media (newspapers, magazines, tabloids) and electronic media (radio, television, films). Now, after the development of communication and information technology, which is marked by the birth of the internet in the midst of modern civilization, the so-called online media emerged. Initially this online media aimed to transfer the news in newspapers or magazines to the internet or known as online. In other words, there is no difference between print and online versions of news products. However, after several months of the reform era, an online media appeared that presented news called detik.com. The Detik.com website does not have a printed version, although in its development it has made a printed version. The print version was short lived and had to be shut down immediately. Then back to online and the news that is displayed is only online. The existing news is also always up to date so that it becomes a reference for many people. (www.antaranews.com accessed 17 September 2015 at 13:35 WIB).

The intelligence, sophistication, and facilities caused by the progress and development of information 
communication technology have become a separate history for the birth of online journalism. People tend to be enthusiastic and dynamic in responding to the proliferation of various information and news presented by online media. In fact, it is clear that communication technology provides enormous benefits for its users, especially in terms of communicating (news delivery becomes very fast). Telecommunication technology also makes the world closer and closer because time and distance are getting shorter, the movement of information goes quickly and spreads according to the desired destination.

There are four types of information media, namely traditional media (newspapers, magazines, radio, and television), online media, social media, and media owned by online media companies which have the highest percentage of $27 \%$. Meanwhile, traditional media is slightly adrift of $1 \%$ with online media, which is $26 \%$. These data show that the power of the internet in disseminating information is unbeatable. Moreover, today's society tends to be mobile, so they need to get information about an event quickly, precisely, and accurately. (500 most favorite sites in the world Alexa version.

\section{CONCEPTUAL FRAMEWORK}

According to Henry Jenkins (2006), what is meant by convergence is a word that manages to describe technological, industrial, cultural, and social changes that depend on who is speaking and what they think they are talking about. Finally, the next definition is formulated in the Dictionary of Media, which states that the term convergence refers to media convergence, namely the process by which old media and new technology media are available separately or together through digitization. Thus, it can be said that media convergence refers to convergence, namely the idea of traditional media forms that are slowly disappearing and shifting together to the internet. Convergence is not just limited to technology. Media theorist Henry Jenkins argues that convergence is not an end result but a process that changes how media is produced and consumed. According to Jenkins, there are five processes that change media produced and consumed, namely: 1. Economic convergence occurs when one firm controls several products or services in the same industry. For example, PT Media Nusantara Citra Tbk, a media company in Indonesia that provides services in the television broadcasting industry (RCTI, GTV, MNC TV, INews TV), print media (Koran SINDO), radio networks (MNC Trijaya FM), and others. other.

2. Social or organic convergence occurs when a person watches various types of television programs or television broadcasts online and at the same time conducts online communication in the form of exchanging text messages with friends while also listening to music. 3 . Technological convergence is the unification of various technologies, namely when one or more different media are transformed into digital form. 4. Cultural convergence occurs when stories flowing across multiple media forms are one component. For example, a novel that became a television series such as Band of Brothers. 5. Global convergence is the process of geographically distant cultural influences on other cultures. For example, the Bollywood film industry in India is inspired by the Hollywood film industry in the United States. The various types of convergence above will certainly have an effect on humans at various levels, both at the individual and social levels. Some theorists believe that convergence and new media technologies are making humans much smarter when it comes to making decisions and interacting with the media they consume.

On the other hand, there are some concerns that the digital age gives everyone wider access to more information but also leaves us with a shallowness. Mark Poster stated that there is a new period in which interactive technology and network communication, especially cyberspace will change society. Can be described as: 1) Two-way 2) Out of control situation 3) Democratization 4) Raising individual awareness 5) Individual orientation New media are considered to be more interactive and create a new understanding of personal communication. The virtual world provides a virtual meeting place that expands the social world, creates new knowledge opportunities, and provides a place to share views widely. (Stephen W Littlejohn, 2009) Media has several characteristics. The first is synchronicity or time distance. In some media communication situations, there is a substantial time gap between message production and message consumption. But there is also media communication without time lag. In addition to synchronicity, which is also a characteristic of the media is interactivity, which means how much influence the communicator and communicant have to control each other's time and message content. Carrie Heeter reclassifies media based on the dimensions of interactivity (E. Comb, 1983). The classification includes the complexity or choices available, the amount of effort made by the audience to obtain media activity, the responsiveness of the media to the audience, monitoring of the audience, the ease with which audiences add information, and facilitating interaction between audiences. The last characteristic of media is privacy.

Public media consumption is when the content of the media message must be consumed en masse. Meanwhile, now the tendency is that individuals prefer to consume media privately for personal convenience. Traditionally, there are uniqueness in each form of media that distinguishes the type and function from one media to another. For example, newspapers are a special medium for conveying hot news, television is a medium of entertainment. But according to Ruben, many of these traditional distinctions have now become blurred. For example, the Internet has now provided a lot of hot and actual news like newspapers, even 


\section{METHOD}

The method in this research is using the case study method, which states that a case study is an approach to study, explain or interpret a case in its natural context without any intervention from outside parties (Robert K Yin, 2002). Cases have their own boundaries, scope of study and mindset; so that it can reveal a unique, specific and challenging social or physical reality. Case studies reveal many things that are very detailed, see what things cannot be revealed by other methods, and can capture the meaning behind the case in the condition of the object naturally.

Data analysis is the process of systematically searching and compiling data obtained from interviews, observations and documentation, by organizing data into categories, describing them into units, synthesizing, compiling into patterns, choosing which ones are important to be studied and making conclusions so that they are easily understood by themselves and others (Bagong, Suyanto and Sutinah. 2007.) Validity shows the actual state and refers to the fit between constructs, or the way a researcher conceptualizes an idea in a conceptual definition and a measure. This refers to how well ideas about reality "fit" with actual reality. In simple terms, validity addresses the question of how well the social reality measured through research fits the constructs that researchers use to understand it (Neuman, W. L. (2007).

\section{RESULT}

Analysis of the Convergence Concept Liputan6. com Reform is the opening gate for freedom of media coverage. This has resulted in the Indonesian press being more guerrilla in exposing various news. One form of the guerrilla in exposing the news is the emergence of many online media. Online media which is generally a means of communication today, has turned out to be an alternative media in answering the impasse of information needs. As a result, there is a lot of information that enters the cognitive, affective and psychomotor community. Then what happens is a confusion of information The emergence of various online media with the segmentation of young people as an implication of the mushrooming use of the internet, is the starting point for young people to become aware of information. These online media or news portals have started to turn young people into a new market for their industry, starting from content adapted to the conditions of young people's knowledge, entertainment information, lifestyle information and information about health, all of which are directed to the needs of young people, percentages for the needs of parents too. looks very little let alone the needs of children. In packaging the appearance of young people, it is always the concern of liputan 6 com. Therefore, Liputan 6 com makes its own rules in selecting the information to be displayed. The level of privatization is also an option in determining information, meaning how feasible the news can be consumed by the audience. It is interesting when in liputan6.com, news that is not suitable for consumption by young people always appears on the screen with the question "are you 18+", this is what selects the content that is suitable for consumption for young people. This is what makes liputan6 com different from other online media. Liputan6.com has its own benchmark for news indicators and audiences that will be used as content, because this content is an important aspect for an online media, so Liputan6.com does not want to compromise in choosing this content.

Because for Liputan6 com, the content in online media will reflect the overall content of the online media. The concept that has been carried has remained the same since the beginning of the emergence of this online media or news portal, namely actual, sharp and reliable. What it means here is that news that is more directed to young people should not prioritize the interests of one group or take sides, even if the news content is found to be biased, the author will be penalized. Liputan6 com is here to remove the negative stigma attached to online media or news portals.

Online media or news portals that seem serious and full of political nuances, by Coverage 6.com are packaged with a good appearance, especially because the target audience is young people, since its appearance Liputan 6 com has emphasized that the packaging and contents are for the needs of readers. young adult. So that all channels and presentation content does not lead to the needs that exist in the world of young people. The Role of Convergence and Participatory Culture on Liputan6. com The presence of news portals or online media with youth segmentation is a distinct color in the realm of the mass media industry in Jakarta. This mobile portal attracts the public's attention to information on the popularity of youth style trends. So it's no wonder these news portals are competing to display the latest information as an attraction. This brings renewal to the increasingly bright mass media industry. Based on the results of an interview with the Vice Editor in Chief of Liputan6.com, it can be seen that since Liputan 6 in 2012, this news portal has continued to improve in terms of appearance. Even though there are currently a lot of online media popping up, Liputan6.com, from the beginning, has planned to display online media that can meet the information needs of young people. All Liputan6.com workers had in- depth discussions about the online media outbreak that was endemic in Indonesian society at that time. However, the findings are the opposite. Liputan6.com readers who are active young people claim to prefer Liputan 6.com at this time, opening a gadget or opening a computer looking for information is facilitated by various means available on Coverage 6.com especially video streaming, further increasing the accuracy of the information provided. there is. The development of online media Liputan 6.com indicates that the mass media industry is not over. 
With a significant increase in viewers, it is proof that the online media industry is shining. Liputan6.com's work in the mass media industry brings a new spirit to the nuances of online media. The segmentation is made more diverse in order to meet market demands. Various tips are done to maintain reader loyalty. The more The increasing number of competitors makes these magazines continue to strive to provide content that is in accordance with the times. If observed further, the social interactions that occur in the production of online media give birth to social changes that occur in society. The result of this social interaction then has a great influence on society. Media coverage of lifestyle shows that the public's interest is very large for the news. This gave birth to a large market demand for the latest information about lifestyle. In its function as a forum for informative news by disseminating various news and information, the media can also act as simulation agents. In this case the media can construct a news. Artificial reality can be processed in such a way that it becomes a real reality. Also the facts of the existing reality can be formed to enrich the real situation. This depends on what the purpose of the media is. In creating an image of reality, the media is able to create a hegemonic view of a news report. With this ability, the media builds its electability. If broadcasting information about lifestyle is the beginning of the birth of Liputan 6 com with the segmentation of young people, then Liputan 6.com does not want to be considered as an outdated news portal or online media. This then makes the news portal or other online media experience a slight shift in purpose. In addition to maintaining reader loyalty, political economy is also applied in the production of the news portal or online media. This is done in order to maintain the existence of the news portal or online media. The pressures that come push the news portal or online media to take actions that can maintain the continuity of the production of the news portal or online media. Various tips were taken to strengthen its business lines in the mass media industry. Liputan 6.com's gait is proven to have brought its own color that revived the mass media industry.

\section{DISCUSSION}

In the initial observation of the problem formulation by the researcher, what the researcher observed was the convergence of online media in winning the competition for the mass media industry in Indonesia, a case study of the news portal Liputan6.com. The time of observation was carried out from August 2015 to March 2016, from the results of observations and in-depth interviews of this study based on two theories used, namely Michael Poster's New Media theory and Henry Jenkins' Media Convergence Theory and Jenkins' Participation Culter Theory. Media Convergence Theory and Participation Culure, regarding the convergence of mass media, the description of the understanding below relates to the news portal www. Liputan.com.

Factors that prompted the establishment of Liputan 6.com The stronger use of the internet has made the mass media an incentive to be creative with their news, both in providing information, entertainment and opinions to the audience. Internet in Indonesia began to exist and became an industry in the 1990s, when a number of people founded RadNet. RadNet was the first commercial internet company. At the end of 1995 it was estimated that there were 15 thousand internet users in Indonesia. Since then it can be said that the internet has become a trend in every Indonesian organization, be it profit, non-profit, government, NGO, and media institutions. can be called the first media to have a website on the Internet, followed by Kompas, and then almost all print and television media, and radio.Detik.com became the first news site in Indonesia, followed by astaga.com, satunet.com and then others. The media is an important path to find and reveal the identity of the media itself, because society needs identity symbols to be manifested in the public space. Religious symbols, group symbols cannot be separated from media convergence which later developed into a lifestyle. In the online media industry, especially news portals, news portals were born which became the extension of a TV station or a news program with various segments that were highlighted according to the needs of the media. According to www.internetworldstaats.com data from around 6.5 billion people in the world in 2008, almost 1.5 billion of them use the internet. Readers or audiences of online media continue to grow, on the contrary, print media readers continue to decline. Therefore, almost all print media now have sites to develop reader behavior. In 2000, internet users in a number of Southeast Asian countries were less than 5 million people. Indonesia is a country with the largest internet users in Southeast Asia. Internet users in Indonesia itself continue to increase from year to year, as well as the number of internet subscribers in Indonesia increasing from year to year According to the site www. internetworldstaats.com of the total population of 230 million more in Indonesia in 2008, internet users were more than 25 million people, whereas in 2000, users in Indonesia had only reached 2 million people. That means, there is an increase of about $900 \%$ in just 8 years. Asia Pacific Telecom Research estimates that Indonesia's internet users in 2009 amounted to 48.7 million and in 2010 as many as 58.60 million. In Indonesia, a number of media conglomerates also dominate online media; Kompas-Gramedia Group owns kompas.co.id; Media Nusantara Citra (MNC) group owns okezone.com; the Bakrie group owns Kanal One (wwww.vivanews.com). Tempo group owns tempointeraktif.com

The first theory of media convergence is that economic convergence occurs when a firm controls several products or services in the same industry. In some media communi-cation situations, there is a substantial time gap between message production and message consumption. But there is also media communication without time lag. The basis why this 6.com coverage was created is to minimize the gap between message 
production and message consumption considering that internet technology is already embedded in everyday life through existing gadgets, so it is inevitable that message production must be balanced with message needs, especially young people who are almost half of the population. the time is used with the gadgets they have, this is the reason why the synchronization needs to be carried out by 6.com coverage. In addition to Economic Convergence, which is also a characteristic of the media is social convergence, which means how much influence communicators and communicants have to control each other's time and message content. Carrie Heeter reclassifies media based on the dimensions of interactivity. The classification includes the complexity or choices available, the amount of effort made by the audience to obtain media activity, the responsiveness of the media to the audience, monitoring of the audience, the ease with which audiences add information, and facilitating interaction between audiences.

In Liputan 6.com the interactivity created between communicators and their communicants is to involve their audiences through opinion forums, so at Liputan 6.com every news presented is given a comment forum like the picture below, so that the audience feels they have a role in obtaining information and that is what is called Cultural convergence by Henry Jenkins.

The last characteristic of media convergence is Global Convergence, where global convergence is carried out by consuming public media which was previously consumed in mass, but now the tendency is more individual in consuming media, this is done for personal convenience, of course this is an example of existing behavior. On characteristics like this, Liputan 6.com as a media that puts forward the actual motto, sharp and reliable, still provides privacy in every news report, especially those that have an "adult" element considering that the target audience or audience is young people who also reach the age of 15 years, so it needs privacy tools, but on the other hand, the privacy character gives the audience to be more open about what kind of information is needed. This provides an opportunity for Liputan 6.com to provide learning tools to its readers, as illustrated below. If at the beginning we used Henri Jenkins' Media Convergence Theory approach, then the second theory is the concept of Participatory Culture which was also popularized by Henry Jenkins, Liputan 6.com has implemented the concept of Participatory Culture on liputan6.com. According to Henry Jenkins, there are 4 indicators in the concept of participatory culture that is implemented in media convergence theory. These include 1) Affiliations - membership, both formal and informal, in online communities, such as friendster, facebook, Myspace, forums and so on. 2). Expressions - production of new creative forms, such as digital sampling, fan fiction, fan video and so on.3. Collaborative Problem Solving working together in teams, both formally and informally, to complete tasks and develop new knowledge.4). Circulations
- shaping media flows, such as podcasting and blogging. The first indicator is Affiliation, Affiliation is a membership process, both formal and informal in an online community. In Liputan 6. Com applies this concept to a news portal that was formed. This is because there are commodities that are attracting market attention. This commodity is in the form of news that includes information on knowledge, lifestyle, sports show biz, economics and technology information. These commodities are then produced and offered for sale to the public. This happens on the impulse of market demand. This need is present in a wide range and the fulfillment of social needs which includes physical satisfaction to the fulfillment of status in society.

Everything contained in liputan6.com mostly contains commodities that are ready to be thrown into the market. Given the increasing level of demand, 6.com coverage is also competing to reach its audience as closely as possible. The establishment of various facilities, either by opening a video uploader with the name Channel Vidio.com, opening a comment forum and receiving information or news that is covered by the audience as citizen journalism to legalizing football fan communities is one of the steps to keep reaching its readers. This will lead to and foster the loyalty of readers who are formed in groups. Liputan6.com also maintains each of its rubrics in order to keep presenting the latest information. Based on the five forms of Participatory described by Jenkins, one of which is expression, Liputan6.com is identified as making an expression in its coverage. Expression is the production of new creative forms, such as digital sampling, fan fiction, fan video and so on in such a way that it becomes a marketable product. This is what then forms a new culture for the audience The expression that is carried out by liputan6.com is to help the messages contained in the article in such a way that it can construct the concept and purpose of the news portal. Information or news that is generally consumed by parents, can be applied in the form of a cosmopolitan lifestyle, where it is not knowledge that is absorbed or presented to the public who must keep up with the times, but appearance must also be able to follow the needs of the audience. After constructing the concept and purpose of the news portal, then the results of this convergence process are ready to be released to the market. The affiliation carried out by Liputan 6.com is to build a homogeneous audience, namely those who are interested in activities using video to capture with a camera, because the assumption is that everyone today must have a cellphone or smart phone equipped with a camera device, especially young people who sometimes have more than one cellphone or smart phone or gadget. So it is not surprising that social media such as Facebook and Instagram are always widely used by young people as a means to stay present. give awards to audiences who are willing to upload their videos or coverage through Liputan6.com, so that the 3600 marketing strategy is implemented, one of which is word of mouth strategy. 
Collaborative Problem Solving is a process to overcome space and time in social life. Collaborative Problem Solving carried out by liputan 6.com is by integrating in its business which can minimize space and time barriers. Collaborative Problem Solving that occurs in this convergence process occurs when a company is also interested in operating in other stages of production, such as supplying materials, equipment and distribution. Liputan 6.com conducts Collaborative Problem Solving by cooperating with several other protals under the auspices of KMK, such as bintang.com and Vidio.com, which are the development of Liputan 6 TV under the auspices of the Emtek Group. This proves that under the Emtek Group, namely SCTV, Indosiar, O Channel and others, is a media force managed by the same person. The Collaborative Problem Solving conducted by Liputan 6.com aims to support their business in the mass media industry in order to minimize space and time barriers. Various supplies of materials and equipment are needed as a diversification step in the company. Diversification is carried out to protect the company from the effects of recession that may occur in certain fields.Liputan 6.com performs cybernatic convergence in order to maintain their business continuity so that they can survive and compete in the new media industry. Collaborative Problem Solving is the unification of ideas and agencies, processes and social praxis into a cybernatic convergence analysis that is closely related to social change, where social life itself consists of space and time. The process of social change is a process that describes how space and time are produced by agents who act through this Collaborative Problem Solving. Liputan 6.com carries out a Collaborative Problem Solving process by bringing together ideas from each agent formed in a group to form the news portal. The agents who are members of the group certainly have the same thoughts or ideas which then form an organizational structure or team that works for each rubric on the news portal. then they express their ideas through the medium of a magazine which will be disseminated to the public. The following chart illustrates the concept of media political economy carried out by coverage of 6.com. Understanding media convergence through Participatory Culture which is applied in each business of Liputan 6.com in order to maintain the continuity of the company. Economic pressure is indeed the main reason to strengthen its business defenses from various lines. Apart from the function of the media to disseminate information or news to the public, now the media is used as a means for entrepreneurs or other capital owners to expand their market reach. By constructing ideas into a social reality, they also form public opinion about their company image.

\section{Analysis of the Convergence Concept Liputan6.com}

Reform is the opening gate for freedom of media coverage. This has resulted in the Indonesian press being more guerrilla in exposing various news. One form of the guerrilla in exposing the news is the emergence of many online media. Online media which is generally a means of communication today, has turned out to be an alternative media in answering the impasse of information needs. As a result, there is a lot of information that enters the cognitive, affective and psychomotor community. Then what happens is a confusion of information The emergence of various online media with the segmentation of young people as an implication of the mushrooming use of the internet, is the starting point for young people to become aware of information. These online media or news portals have started to turn young people into a new market for their industry, starting from content adapted to the conditions of young people's knowledge, entertainment information, lifestyle information and information about health, all of which are directed to the needs of young people, percentages for the needs of parents too. looks very little let alone the needs of children. In packaging the appearance of young people, it is always the concern of liputan6 com. Therefore, Liputan 6 com makes its own rules in selecting the information to be displayed. The level of privatization is also an option in determining information, meaning how appropriate the news can be consumed by the audience. It is interesting when in liputan6.com, news that is not suitable for consumption by young people always appears on the screen with the question "are you 18+", this is what selects the content that is suitable for consumption for young people. This is what makes liputan6 com different from other online media.

What's odd is that when someone is trapped to enter a portal that is thought to contain elements of sexuality, it turns out that it only contains advertisements, or provides a special column for placing advertisements. The more that enter the portal, the more ads appear. This must be interpreted that the audience as a product is expensive. The reality shows that there are many people who watch sexuality-related shows and bring high income for portal managers. Second, the audience as workers. In this domain surfing in cyberspace cannot be considered merely as a mere psychological relaxation activity. Staring at a glass screen that presents various information is work. When the audience is converted into rating figures at the same time showing how watching a computer or smartphone screen is recorded as a job in itself. This means that the portal owner constructs the audience not only as spectators, but also as workers.

The online media portal business is not only a matter of the impression economy, but the economy of the audience as well. A portal can only be successful when the number of visitors is large, otherwise one that does not have visitors will surely lose. This can be likened to a factory that employs workers, if the number of workers working in a factory is abundant then the factory is considered successful. On the other hand, if the factory workers are few in number, or even none at all, then the factory is considered a failure. This is the reality that 6. com coverage also faces in packaging news content for the needs of its audience. 
The content is packaged in such a way that the audience is willing to read and comment, when the audience is able to comment, the news portal will also obtain data in the form of advertising sources.

The content contained in liputan6 com cannot be separated from the influence of the surrounding environment. Based on the previous discussion by Shoemaker and Reese, there are several levels or levels that can influence media content, namely the individual level, the level of media routines, the organizational level, and the ideological level. In practice, these five factors have been shown to influence media content. The content contained in liputan6.com cannot be separated from the influence of the characteristics, backgrounds, and experiences of the individuals who work in it. When the characteristics and routines of liputan6.com are formed, the unity of the organization will affect the content of the media depending on the focus of the organization. Liputan6 com is a news portal with private ownership status where the purpose, focus and agenda of media content is absolutely determined by the highest authority in its organizational structure. It is not impossible if external parties influence media content. Shoemaker and Reese also mention that there is an extra level of media that can affect the content of media content.

This relates to parties who have personal interests. Liputan6.com contains various advertisements that increase the selling value of the media. This cannot be separated from the interests of external parties who will then give certain interests to the media that contains the advertisements. In the end, things that affect media content, both in terms of individuals, routines, and external parties will form an ideology rooted in liputan6.com. The ideological level is a crucial thing that will show how the role of the media in social life will be. This ideology will determine what the role of the media will be in the future. The production of Liputan6.com cannot be separated from the interaction of its workers. Where these social interactions give birth to innovative new thoughts. New thoughts This is what then forms an identity for each news portal that is ready to compete in the realm of the mass media industry, especially in Jakarta. This shows that Liputan6.com has a strong character attached to its readers. It is not impossible that the concepts in these news portals will influence young people in shaping themselves so that they have an impact on social life. In connection with the processes that initiate the level of human behavior, an individual will think about what his image looks like and then what he imagines it to be, then how to place himself in the social environment around him, then social interaction occurs. The higher a person's ability to play a social role, the more identity or identity is formed.

\section{The Role of Convergence and Participatory Culture on Liputan6.com}

The presence of news portals or online media with youth segmentation is a distinct color in the realm of the mass media industry in Jakarta. This mobile portal attracts the public's attention to information on the popularity of youth style trends. So it's no wonder these news portals are competing to display the latest information as an attraction. This brings renewal to the increasingly bright mass media industry. Based on the results of an interview with the Vice

Editor in Chief of Liputan 6.com, it can be seen that since Liputan 6 in 2012, this news portal has continued to improve in terms of appearance. Even though there are currently a lot of online media popping up, Liputan6.com, from the beginning, has planned to display online media that can meet the information needs of young people. All Liputan6.com workers had in- depth discussions about the online media outbreak that was endemic in Indonesian society at that time. However, the findings are the opposite. Liputan6.com readers who are active young people claim to prefer Liputan6.com at this time, opening a gadget or opening a computer looking for information is facilitated by various facilities available on liputan6.com especially video streaming, further increasing the accuracy of the information available. . The development of online media Liputan6.com indicates that the mass media industry is not over. With a significant increase in viewers, it is proof that the online media industry is shining. Liputan6.com's work in the mass media industry brings a new spirit to the nuances of online media. The segmentation is made more diverse in order to meet market demands.

Various tips are done to maintain reader loyalty. The increasing number of competitors makes these magazines continue to strive to provide content that is in accordance with the times. If observed further, the social interactions that occur in the production of online media give birth to social changes that occur in society. The result of this social interaction then has a great influence on society. Media coverage of lifestyle shows that the public's interest is very large for the news. This gave birth to a large market demand for the latest information about lifestyle. In its function as a forum for informative news by disseminating various news and information, the media can also act as simulation agents. In this case the media can construct a news. Artificial reality can be processed in such a way that it becomes a real reality. Also the facts of the existing reality can be formed to enrich the real situation. This depends on what the purpose of the media is. In creating an image of reality, the media is able to create a hegemonic view of a news report. With this ability, the media builds its electability.

If broadcasting information about lifestyle is the beginning of the birth of Liputan6 com with the segmentation of young people, then Liputan6.com does not want to be considered as an outdated news portal or online media. This then makes the news portal or other online media experience a slight shift in purpose. In addition to maintaining reader loyalty, political economy is also applied in the production of the news portal or online media. This is done in order to maintain the existence of the news portal 
or online media. The pressures that come push the news portal or online media to take actions that can maintain the continuity of the production of the news portal or online media. Various tips were taken to strengthen its business lines in the mass media industry.

Liputan6.com's gait has proven to bring its own color that revives the mass media industry. In this study, the researcher tries to answer the problem formulation that has been stated previously, namely the convergence of online media in winning the competition for the new media industry in Indonesia (Case study on Liputan6. com). In the production of the news portal or online media. Researchers reveal the factors driving the birth of the Liputan6.com news portal, analysis of the convergence concept promoted by liputan6.com, and its role in the new media industry in Indonesia. Based on the data that has been described in the previous chapter, the researcher can draw several conclusions as follows:

1. As a news portal or online media, Liputan6 com whose base of media activity depends on internet facilities in charge of socializing or disseminating news. So through this research it was declared successful, because wherever people are can enjoy the information that is disseminated through the internet network, many internet users, especially young people, can receive the information offered because Liputan6.com offers speed, accuracy and variety, because that is the value. selling from Liputan6.com, which, if it is not done, will be abandoned by readers.

2. As a news producer in the New media industry, Liputan6. com has developed a technique to obtain information as quickly and as accurately as possible, namely by prioritizing the concept of Citizen Journalism or citizen journalism. where Liputan6 com in its news coverage Liputan6.com engages the community, considering that currently mobile phone technology has been equipped with video and camera facilities, and this is seen as participatory culture in Henry Jenkins' thought

3. Whereas Liputan6.com in carrying out participatory culture in the New Media industry is to meet the information needs of young people who are its target audience, it is not unusual if information on Liputan 6.com leads to information that is entertainment or known as infotainment. creates interesting interactivity, namely word of mouth, and this is a manifestation that Liputan6.com can influence the minds of its readers.

4. The audience, who is actually young people, also becomes aware which information is general and which information is private when the media teaches it and Liputan6.com has also taught it by blocking adult content, so that when the audience synchronizes news By doing socialization to other parties, they will realize that this is appropriate or not.

5. Liputan6 com was identified as applying the political economy of media in its news production, especially in terms of convergence, either in content or intrinsic convergence, namely by presenting more information on entertainment, then audience convergence or extrinsic, involving citizens to collect news and disseminate it which is called citizen journalism and cybernatic convergence, namely reducing the boundaries of space and time by continuing to spread news, namely by sharing on other media, be it Yahoo.com, Vivanews. com and other social media.

\section{REFERENCES}

Salim, Agus . 2001 Teori dan Paradigma Penelitian Sosial Yogyakarta: Tiara Wacana Yogya, Atmakusuma,

Maksum Iskandar, 2003 Melacak Jurnalisme Media Siaran Dan Internet, Jakarta. RMBOOKS

Mulyana, Dedy, 2003 Ilmu Komunikasi, Suatu Pengantar, PT. Remaja Rosdakarya, Bandung. Mc Quail, Denis. 1987

Teori Komunikasi Massa, terj. Agus Dharma dan Aminuddin Ram Jakarta: Erlangga.

Wahyudi, J, B. 1986. Komunikasi Massa Televisi, Alumni, Bandung.

Rakhmat, Jalaluddin 1991 Psikologi Komunikasi, Edisi Reivsi, Bandung, Remaja, Rosdakarya.

Moleong, Lexy ,J. 2000 Metodologi Penelitian Kualitatif PT Remaja Rosda Karya Bandung.

Romli,M, Syamsul, Asep 2000 Jurnalistik Online: Panduan Praktis Mengelola Media Online Bandung, Nuansa Cendekia.

Denzin, NK. dan Lincoln, YS (eds),2000 Handbook of Qualitative Research (Second Edition), Thousan Oaks, London, New Delhi: Sage Publication.

Effendy, Uchjana Onong 2000. Ilmu Komunikasi Teori dan Praktek, PT. Remaja Rosdakarya, Bandung.

Kriyantono, Rachmat 2010 Teknik Praktis Riset Komunikasi, Prenada Media Group. Sendjaja, Djuarsa, Sasa, 2000. Pengantar Ilmu Komunikasi, Universitas Terbuka.

Karlinah, Siti. 2000 Komunikasi Massa, Universitas Terbuka, Jakarta. Sugiyono, 2008 Metode Penelitian Pendidikan, Bandung: CV. Alfabeta.

Arikunto, Suharsimi ,1998. Prosedur Penelitian, Suatu Pendekatan Praktek Jakarta: Rineka Cipta.

Turner,L.H.\&West,R.L.2007IntroducingCommunication Theory: Analysis and Application,3rd Ed. New York: McGraw-Hill.

Ks , Usman, 2009 Ekonomi Media, Pengantar Konsep dan Aplikasi, Bogor : Ghalia Indonesia

Jenkins, Henry. et. al, 2009. Confronting The Challengess of Participatory Culture: Media Education for the 21st Century, Massachusetts: MIT Press. 
Jenkins, Henry. 2004.Convergence Culture: Where Old and New Media Collide, New York: New York University Press.

Wazis, Kun 2012. Media Massa dan Kontruksi Realitas,Jakarta Aditya Media P u b l i s h ing . Severin, Werner J -. Tankard, Jr, James W. 2007 Teori Komunikasi: Sejarah,Metode, Dan Terapan di Dalam Media Massa, (Jakarta: Kencana Prenada Media Group, Ed ke-5, Cet. 2,.

Wimmer \& Domminick 1991. Mass Media Research: An Introduction. USA: Cencage Learning.

Zaenuddin, HM, 2011 The Journalist, Bandung: Remaja Rosdakarya,

Kamus Besar Bahasa Indonesia, Edisi ke-dua Tahun 1989. Kbbi.we.id/guna diunduh tanggal 23 Agustus 2015 pukul 20.08 WIB www.antaranews. Com akses 17 September 2015 pukul 13:35 WIB.

www. Liputan6.com diunduh pada tanggal 31 Oktober 2015 pukul 13.30 wib

Astriani ,Amelia, Yufinna, W, Analisis Berita Pra KLB Partai Demokrat Di Media ViVA. CO.ID dan Liputan6.com, Universitas Mulawarman .2014

Prihantoro, Edi, Analisis Wacana Pemberitaan Selebriti Pada Media Online www. Kompas.com, www. mediaindonesia.com, www.detik.com, www. Liputan 6.com Universitas Gunadarma Jakarta, 2013.

Artha ,Aprilia ,Devfanny Representasi FPI pada Media Online (Analisis Wacana Kritis terhadap Portal Berita Liputan6.com) Universitas Indonesia ,201 